\title{
Comparison of the global gene expression profiles in the bovine endometrium between summer and autumn
}

\author{
Ryosuke SAKUMOTO'1), Ken-Go HAYASHI' ${ }^{1)}$, Shiori SAITO ${ }^{1)}$, Hiroko KANAHARA ${ }^{1)}$, \\ Keiichiro KIZAKI') and Kosuke IGA ${ }^{3)}$ \\ 1)Animal Physiology Research Unit, National Institute of Agrobiological Sciences, Ibaraki 305-0901, Japan \\ 2) Laboratory of Veterinary Physiology, Iwate University, Iwate 020-8550, Japan \\ 3) NARO Tohoku Agricultural Research Center, Iwate 020-0198, Japan
}

\begin{abstract}
Heat stress compromises fertility during summer in dairy and beef cows by causing nutritional, physiological and reproductive damages. To examine the difference in endometrial conditions in cows between summer and autumn, gene expression profiles were compared using a $15 \mathrm{~K}$ bovine oligo DNA microarray. The trial was conducted in the summer (early in September) and autumn (mid-November) seasons of two consecutive years (2013-2014) in Morioka, Japan. Endometrial samples were collected from the cows using a biopsy technique. The expressions of 268 genes were significantly higher in the endometrium collected in summer than those collected in autumn, whereas the expressions of 369 genes were lower $(\mathrm{P}<0.05$ or lower). Messenger RNA expressions of glycoprotein 2 (GP2), neurotensin (NTS), E-cadherin (CDH1) and heat shock $105 \mathrm{kDa} / 110 \mathrm{kDa}$ protein 1 (HSPH1) were validated by quantitative real-time PCR. Transcripts of GP2 and NTS were more abundant in the endometrium from summer than in the endometrium from autumn $(\mathrm{P}<0.05)$. In contrast, the mRNA expressions of $C D H 1$ were lower $(\mathrm{P}<0.05)$ and those of $H S P H 1$ tended to be low $(\mathrm{P}=0.09)$ in the endometrium from summer. Immunohistochemical staining showed that GP2, NTS and HSPH1 were expressed in the endometrial epithelial or glandular epithelial cells. The serum concentrations of NTS collected from the cows in summer were higher than those collected from cows in autumn $(\mathrm{P}<0.05)$. Collectively, the different gene expression profiles may contribute to functional differences in the endometrium between summer and autumn, and the increases in GP2 and NTS may have a relationship with the endometrial deficiency that causes infertility of cows in summer.
\end{abstract}

Key words: Cow, Endometrium, Heat stress, Infertility, Microarray analysis

(J. Reprod. Dev. 61: 297-303, 2015)

C onception rate to first service declined from $60 \%$ to $30-40 \%$ over the past 25 years in the world [1]. There are clear seasonal patterns in conception rate, especially in dairy cows [2-4] and lower conception rates are consistently observed in summer months compared with winter months $[5,6]$. Both appetite and dry matter intake are reduced by heat stress [7], thus prolonging the period of postpartum negative energy balance and increasing the calving-conception interval $[8,9]$. Heat stress reduces summer fertility both in dairy and beef cows by causing poor estrous expression due to reduced estradiol secretion from the dominant follicle developed in a low luteinizing hormone (LH) environment [10-12]. Moreover, heat stress inhibits oocyte growth by altering progesterone, $\mathrm{LH}$ and follicle-stimulating hormone secretion during the estrous cycle [7]. Abnormal profiles of progesterone as well as prolactin (PRL) may induce infertility in buffaloes during a hot summer [13]. Heat stress has also been associated with impaired embryo development and

Received: February 25, 2015

Accepted: April 8, 2015

Published online in J-STAGE: May 19, 2015

(C)2015 by the Society for Reproduction and Development

Correspondence: R Sakumoto (e-mail: sakumoto@affrc.go.jp)

This is an open-access article distributed under the terms of the Creative Commons Attribution Non-Commercial No Derivatives (by-nc-nd) License $<\mathrm{http}: / /$ creativecommons.org/licenses/by-nc-nd/3.0/>. increased embryo mortality in cattle [14-16]. Understanding the physiological differences in endometrial function between summer and autumn might help to determine a way to improve reproductive efficiencies and reduce the number of defective fetuses.

Therefore, in the present study, we looked for differences in global gene expression patterns in the bovine endometrium obtained by biopsy in summer and autumn seasons using a custom-made $15 \mathrm{~K}$ bovine oligo DNA microarray. Since the expressions of some genes including glycoprotein 2 (GP2), neurotensin (NTS), E-cadherin (CDH1) and heat shock $105 \mathrm{kDa} / 110 \mathrm{kDa}$ protein 1 (HSPH1) changed drastically between summer and autumn, gene and protein expressions of these substances in the endometrium or serum were also investigated.

\section{Materials and Methods}

Animals

All procedures for animal experiments were carried out in accordance with guidelines approved by the Animal Ethics Committee of the NARO Tohoku Agricultural Research Center (Morioka, Japan) for the use of animals.

Sampling procedures were carried out in the summer (early in September) and autumn (mid-November) seasons of two consecutive years (2013-2014) in Morioka, Japan. These periods were selected because empirically derived conception rate are low in the summer 
Table 1. Temperature (C) and humidity (\%) for $0700-1700 \mathrm{~h}$ during 45 days before the day of sampling in summer and autumn

\begin{tabular}{lcccccccc}
\hline & & \multicolumn{3}{c}{ Temperature $(\mathrm{C})$} & & \multicolumn{3}{c}{ Humidity (\%) } \\
\cline { 3 - 5 } \cline { 8 - 9 } & & Mean & Max & Min & & Mean & Max & Min \\
\hline \multirow{2}{*}{ Summer } & 2013 & 25.6 & 34.6 & 15.4 & & 71.1 & 99.9 & 30.3 \\
& 2014 & 25.7 & 34.8 & 16.4 & & 74.0 & 99.9 & 37.2 \\
\hline Autumn & 2013 & 11.5 & 27.4 & -1.7 & & 73.0 & 99.9 & 33.2 \\
& 2014 & 13.0 & 24.4 & 1.1 & & 68.4 & 99.9 & 25.9 \\
\hline
\end{tabular}

and are high in the autumn. Daily high, low and mean ambient temperatures and humidity were recorded every $1 \mathrm{~h}$ from 0700 to $1700 \mathrm{~h}$ in the pasture area of NARO Tohoku Agricultural Research Center using a temperature and humidity SD data logger (AD-5696, A\&D, Tokyo, Japan). The data for ambient temperature and humidity (mean, maximum and minimum) during 45 days before the sampling day are shown in Table 1.

Three nonpregnant Japanese Black cows (2.5 to 4 years of age with normal estrous cycles) were used in each year (individual ID \#206, \#207 and \#321 in 2013 and \#217, \#230 and \#326 in 2014). The cows used in 2013 and 2014 weighed $399 \pm 8.0 \mathrm{~kg}$ and $447 \pm$ $22.4 \mathrm{~kg}$, respectively. The cows were housed in identical chambers in the same shelter under the same husbandry conditions from 1700 to $0700 \mathrm{~h}$ and had access to native grass pasture and hay from 0700 to $1700 \mathrm{~h}$. Cows were housed in groups under the same nutritional conditions and received water from metal tanks ad libitum in the pasture area. Endometrial tissues and blood samples were obtained from three cows (\#206, \#207,\#321) in both the summer and autumn seasons of 2013. The same operations were conducted using another three cows (\#217, \#230, \#326) in 2014. A total of six cows were used in the experiments.

For synchronization of estrus, a controlled internal drug release device (CIDR; EAZI-BREED, Surge Miyawaki, Tokyo, Japan) was inserted for 4-6 days at day 10-14 of the estrous cycle, and $0.5 \mathrm{mg}$ cloprostenol, a prostaglandin (PG) $\mathrm{F}_{2 \alpha}$ analogue (Estrumate; Nagase Medicals, Itami, Hyogo, Japan), was injected i.m. on the same day as the CIDR treatment. Estrus was checked visually by heat mount detector (QuickStick; Kamar Products, Zionsville, IN, USA). Cows expressing estrous behavior within $39 \mathrm{~h}$ after removal of the CIDR were included in the experiment. On day 2 of the estrous cycle, ovulation was confirmed by ultrasonography with a $9 \mathrm{MHz}$ linear array transducer (Apron EUB-7000HV, Hitachi Medical, Tokyo, Japan).

\section{Collection of bovine endometrial tissues}

Endometrial biopsies were obtained with a biopsy instrument (Yamauchi Methods, FB141, Fujihira, Tokyo, Japan) using a previously described method with slight modifications $[17,18]$. Samples were obtained from the cows at day 15 of the estrous cycle. The day of estrus was designated as day 0 . Briefly, after cleaning the perineum and external genitalia, the biopsy instrument in a protective sheath was introduced into the vagina. The instrument was guided into the cervix by manipulation per rectum. Then the instrument alone was introduced into the uterus after rupturing the sheath at the external cervical orifice and guided into the previously gravid horn approximately $3 \mathrm{~cm}$ past the uterine bifurcation. To ensure reproducible tissue procurement, the tip of the biopsy instrument inside the uterus was identified using the nonoperating hand per rectum. Then the biopsy jaws were opened, and, with the help of the hand in the rectum, the medial uterine wall was gently pressed into the instrument jaws. Endometrial tissue was clipped off by closing the jaws and withdrawing the instrument. All biopsies were performed by the same operator. The tissue was then placed on sterilized dishes. For molecular analysis, endometrial tissues were cut into small pieces $\left(<0.5 \mathrm{~cm}^{3}\right)$, cryopreserved in liquid nitrogen and then stored at $-80 \mathrm{C}$ for later processing. For endocrinological analysis, blood samples were collected from the jugular vein at just before biopsy and centrifuged at 3,300 $\times g$ at $4 \mathrm{C}$. Plasma samples were stored at $-30 \mathrm{C}$ until use. For histologic assessment, bovine endometrial tissues were obtained from Japanese Black cows at the institute ranch within 10-30 min of exsanguination, and tissue samples were collected from cows on day 15 of the estrous cycle $(n=3)$.

\section{Microarray analysis}

A custom-made $15 \mathrm{~K}$ bovine oligo DNA microarray (GPL9284) was used for the microarray analysis, which was performed as described previously [19]. After verifying the quality of the RNA with a NanoDrop ND-1000 spectrophotometer (NanoDrop Technologies, Wilmington, DE, USA), and an Experion RNA StdSens Analysis Kit (700-7104JA, Bio-Rad Laboratories, Hercules, CA, USA), we performed one-color microarray analysis. RNA integrity was confirmed; all samples had an A260/280 ratio greater than 1.8 and an RNA integrity number greater than 8.5 . The oligo microarray produced by Agilent Technologies (Palo Alto, CA, USA) was used in this study. Sixty-mer nucleotide probes for the customized microarray were synthesized on a glass slide. cDNA synthesis, Cy3-labeled cRNA preparation, hybridization and washing and scanning of the array slides were performed according to the Agilent one-color microarray-based gene expression analysis protocol. Briefly, $400 \mathrm{ng}$ of total RNA from each sample were reverse transcribed into cDNA using a Quick Amp Labeling Kit (Agilent Technologies) with an oligo dT-based primer, and then Cy3-labelled cRNA was prepared by in vitro transcription. Labeled cRNA was purified with an RNeasy Mini Kit, and the concentration and Cy3 dye incorporation (pmol Cy3/ $\mu$ g cRNA) were measured with a spectrophotometer. Labeled cRNA (600 ng) was fragmented and hybridized using a Gene Expression Hybridization Kit (Agilent Technologies), according to the manufacturer's instructions. The arrays were washed using a Gene Expression Wash Pack Kit and scanned using an Agilent Microarray Scanner. Feature Extraction ver. 9.5 was used for image analysis and data extraction. The microarray data from each sample were imported into GeneSpring 12 (Agilent Technologies) for further data characterization. The GEO accession numbers are as follows: Platform, GPL9284; samples, GSM1613709 to GSM1613720; series, GSE66057.

\section{Real-time PCR}

Total RNA isolation and subsequent reverse transcription and real-time PCR steps were carried out as previously described [20]. The primers encoding the bovine sequences were chosen using an online software package (http://primer3.ut.ee/) and synthesized as listed in Table 2. The primer length $(20 \mathrm{bp})$ and GC contents 
Table 2. Primers used in real-time PCR

\begin{tabular}{|c|c|c|c|c|}
\hline Gene & & Sequence (5'-3’) & GenBank accession no. & $\mathrm{bp}$ \\
\hline \multirow[t]{2}{*}{ Glycoprotein 2 (GP2) } & For & AGTGAGGATGCCAGAGGACT & NM_001075950 & 149 \\
\hline & Rev & TCTTCCAGAGGCAGCAGTTG & & \\
\hline \multirow[t]{2}{*}{ Neurotensin (NTS) } & For & TCCTGCTGCCTTAGATGGTT & NM_173945 & 105 \\
\hline & Rev & TCCTGAATCAACTCCCAGTGT & & \\
\hline \multirow[t]{2}{*}{ E-cadherin (CDH1) } & For & GATTGCAAGTTCCCGCCATC & NM_001002763 & 145 \\
\hline & Rev & ACATTGTCCCGGGTGTCATC & & \\
\hline \multirow[t]{2}{*}{ Heat shock protein 1 (HSPH1) } & For & TGCAATCCTTTCCCCAGCAT & NM_001075302 & 141 \\
\hline & Rev & GGAGCAGCGTGGTTTCTACT & & \\
\hline \multirow[t]{2}{*}{$R N 18 S 1$} & For & AAACGGCTACCACATCCAAG & DQ222453 & 141 \\
\hline & Rev & TCGCGGAAGGATTTAAAGTG & & \\
\hline
\end{tabular}

of each primer ( 50 to $60 \%$ ) were selected to avoid primer dimer formation. Gene expression was measured by real-time PCR using an Mx3000P Real-time PCR analyzing system (Agilent Technologies) and QuantiFast SYBR Green PCR Kit (204054, Qiagen) starting with $200 \mathrm{ng}$ of reverse-transcribed total RNA. The expression of $18 \mathrm{~S}$ ribosomal RNA (RN18S1) was used as an internal control. The PCR was performed under the following conditions: (first step) $95 \mathrm{C}$ for 5 min; 40 cycles of $95 \mathrm{C}$ for $15 \mathrm{sec}, 60 \mathrm{C}$ for $30 \mathrm{sec}$ and (second step) $95 \mathrm{C}$ for $60 \mathrm{sec}$; and then $60 \mathrm{C}$ for $30 \mathrm{sec}$. The reaction was then held at $25 \mathrm{C}$. Each PCR was followed by obtaining melting curves to ensure single-product amplification. As standard curves, serial dilutions of appropriate cDNA were used for gene quantification. The obtained data were normalized on the basis of RN18S1 mRNA content. Use of the Mx3000P Real-time PCR analyzing system at elevated temperatures resulted in reliable and sensitive quantification of the RT-PCR products with high linearity (Pearson correlation coefficient $r>0.95$ ). To exclude any contaminating genomic DNA, all experiments included controls lacking the reverse transcription enzyme. As a negative control, water was used instead of RNA for the PCR to exclude any contamination from buffers and tubes.

\section{Immunohistochemistry}

Immunohistochemistry for glycoprotein 2 (GP2), neurotensin (NTS), E-cadherin (CDH1) and heat shock $105 \mathrm{kDa} / 110 \mathrm{kDa}$ protein 1 (HSPH1) in the bovine endometrium was performed using an automated Ventana HX System Discovery with a Dab Map Kit (Roche Diagnostics, Mannheim, Germany) as described previously in detail by our laboratory [21]. The endometrial samples for immunohistochemistry were fixed with $10 \%$ neutral formalin for $24 \mathrm{~h}$. Five-micrometer-thick sections from paraffin embedded tissue were incubated at room temperature with rabbit polyclonal anti-human GP2 antibody (LS-B6834, LifeSpan BioSciences, Seattle, WA, USA), rabbit polyclonal anti-bovine NTS antibody (bs-6631R, Bioss, Woburn, MA, USA), rabbit polyclonal anti-bovine CDH1 antibody (bs-1519R, Bioss) or rabbit polyclonal anti-hamster HSPH1 antibody (LS-B7471, LifeSpan BioSciences) diluted 1:25 or 1:50 each in Discovery Ab diluents (Roche) for $12 \mathrm{~h}$. The signals were detected using anti-rabbit IgG-Biotin conjugate (Sigma-Aldrich, St Louis, MO, USA) diluted 1:100 for $1 \mathrm{~h}$ and then counterstained with hematoxylin. Negative controls were performed using normal rabbit IgG (NBP2-24891, Novus Biologicals, Littleton, CO, USA) diluted at concentrations equivalent to the primary antibodies. The sections were observed with a Leica DMRE HC microscope (Leica Microsystems, Tokyo, Japan) and a Nikon Digital Sight DS-Fi1-L2 (Nikon, Tokyo, Japan).

\section{ELISA}

The NTS and CDH1 concentrations in the plasma were determined using commercial bovine ELISA kits (NTS, CSB-EL016136BO, CUSABIO Biotech Wuhan, PR China; CDH1, CSB-EL005034BO, CUSABIO). The ranges of the standard curves were $25-1600 \mathrm{pg} / \mathrm{ml}$ for NTS and 7.8-500 ng/ml for CDH1, respectively. The intra-assay coefficients of variation were $8.8 \%$ for NTS, and $10.6 \%$ for CDH1. The plasma samples were directly used for the ELISA.

\section{Statistical analyses}

Microarray data were analyzed statistically with the Student's $t$-test and summarized using GeneSpring 12 (Agilent Technologies). All extracted microarray data were analyzed with one-way ANOVA followed by the Turkey-Kramer multiple comparison test using the JMP 7 software (SAS Institute, Cary, NC, USA). The correlations between the flow cytometric collection and gradient collection were determined by the Pearson product-moment correlation coefficient using the JMP software, and the correlation coefficients were calculated as r-values. Experimental data for real-time PCR and ELISA are presented as the mean \pm SEM. The statistical significance of differences in the abundance of mRNA expressions and in protein concentrations was assessed by a Wilcoxon-Mann-Whitney U-test with KaleidaGraph 4.1 (Synergy Software, Reading, PA, USA). $P$-values less than 0.05 were considered statistically significant.

\section{Results}

\section{Gene expression profiles in the bovine endometrial tissues}

The expressions of many genes in the endometrium obtained in summer statistically differed by a factor of $>1.0$-fold $(\mathrm{P}<0.05)$ from their expressions in the endometrium obtained in autumn. These included 268 and 369 genes with higher and lower expressions in the endometrium in summer than autumn, respectively. Some of the genes were differentially expressed between the endometria of summer 
Table 3. Fold change in mRNA levels of selected genes in the endometrium obtained from cows in summer and autumn

\begin{tabular}{lcc}
\hline \multicolumn{1}{c}{ Gene } & Change (fold) & P-values \\
\hline (Summer > autumn): total 268 genes & & \\
Glycoprotein 2 (GP2) & 16.48 & 0.035 \\
Neurotensin (NTS) & 10.45 & 0.037 \\
Insulin-like growth factor binding protein 1 (IGFBP1) & 2.55 & 0.049 \\
Chemokine C-X-C motif ligand 3 (CXCL3) & 2.45 & 0.019 \\
ISG15 & 1.88 & 0.007 \\
Placenta-specific 8 (PLAC8) & 1.76 & 0.020 \\
BAX & 1.61 & 0.004 \\
MX1 & 1.54 & 0.025 \\
Cluster of differentiation 83 (CD83) & 1.54 & 0.025 \\
TCRA & 1.52 & 0.025 \\
Endothelin converting enzyme 1 (ECE1) & 1.34 & 0.025 \\
ESAM & 1.30 & 0.036 \\
IL10RB & 1.24 & 0.010 \\
Tissue inhibitor of metalloproteinase 2 (TIMP2) & 1.24 & 0.006 \\
Caspase 4 (CASP4) & 1.20 & 0.042 \\
BOLA-DMB & 1.20 & 0.040 \\
(Summer < autumn): total 369 genes & & \\
E-cadherin (CDH1) & 1.80 & 0.037 \\
Heat shock 105kDa/110 kDa protein 1 (HSPH1) & 1.41 & 0.009 \\
Insulin-like growth factor 2 (IGF2) & 1.36 & 0.044 \\
Prostaglandin D2 synthase (PTGDS) & 1.29 & 0.014 \\
Oviductal glycoprotein 1 (OVGP1) & 1.27 & 0.030 \\
Calmodulin (CALM) & 1.19 & 0.010 \\
Minichromosome maintenance complex component 5 (MCM5) & 1.19 & 0.013 \\
Heat shock 70kDa protein 8 (HSPA8) & 1.18 & 0.010 \\
Progesterone receptor membrane component 2 (PGRMC2) & 1.16 & 0.016 \\
Minichromosome maintenance complex component 7 (MCM7) & 1.11 & 0.003 \\
\hline
\end{tabular}

and autumn (Table 3). The glycoprotein 2 (GP2) and neurotensin (NTS) were the genes with the highest expression, and E-cadherin (CDH1) and heat shock $105 \mathrm{kDa} / 110 \mathrm{kDa}$ protein 1 (HSPH1) were those with the lowest expression in the endometrium in summer compared with autumn.

\section{Expressions of GP2, NTS, CDH1 and HSPH1 in the endometrial tissues}

Messenger RNA expressions of GP2, NTS, CDH1 and HSPH1 were checked by real-time PCR (Fig. 1). Transcripts of GP2 and NTS appeared to be more abundant in the endometrium obtained in summer than that obtained in autumn (Fig. $1 \mathrm{~A}$ and $1 \mathrm{~B} ; \mathrm{P}<0.05$ ). In contrast, the expressions of $\mathrm{CDH1}$ were lower (Fig. $1 \mathrm{C} ; \mathrm{P}<0.05$ ) and those of $H S P H 1$ tended to be low (Fig. 1D; $\mathrm{P}=0.09$ ) in summer compared with autumn.

Immunohistochemical staining showed that GP2, NTS and HSPH1 were clearly expressed in either the endometrial epithelial or glandular epithelial cells (Fig. 2), whereas CDH1-positive immunostaining was not observed in the endometrium used in this study. NTS concentrations were significantly higher in the plasma obtained from the cows in summer than those in the plasma obtained from the cows in autumn
(Fig. 3A; $\mathrm{P}<0.05)$. In contrast, the $\mathrm{CDH} 1$ concentrations in the plasma did not change significantly between summer and autumn.

\section{Discussion}

The preceding results are the first to demonstrate the number of genes whose expressions changed in the endometrium during the transition between summer and autumn. In addition, some of the genes, including GP2 and NTS, showed drastically upregulated expressions in the endometrium in summer. These observations suggest that the different expressions of these specific substances were related to infertility of the cows during summer.

It has been demonstrated that heat stress during the hot months continues to suppress antral follicles on days 40-50 [22, 23]. Heat stress reduces gonadotropin-releasing hormone $(\mathrm{GnRH})$ and $\mathrm{LH}$ secretion [24, 25] and causes low blood estradiol concentrations by reducing the steroidogenic capacity of theca and granulosa cells in the dominant follicles $[26,27]$. In contrast, the effects of heat stress on plasma progesterone concentrations in dairy cows differ depending on the study, with some showing that they were increased $[28,29]$, decreased [7] or unchanged [27, 30]. These endocrine 
(A) Glycoprotein 2

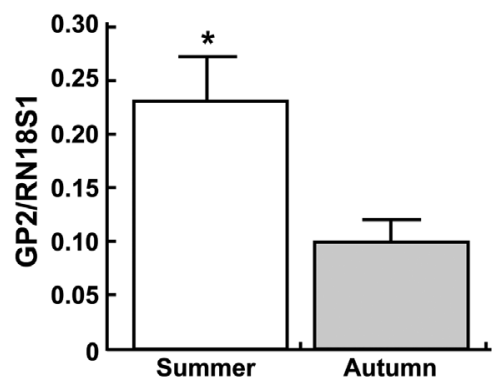

(C) E-cadherin

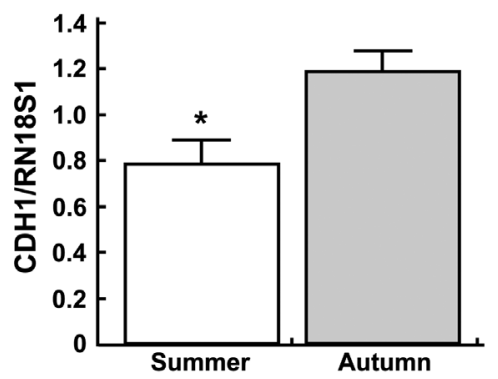

(B) Neurotensin

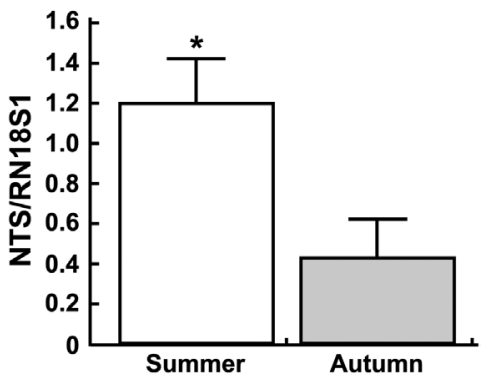

(D) Heat shock protein 1

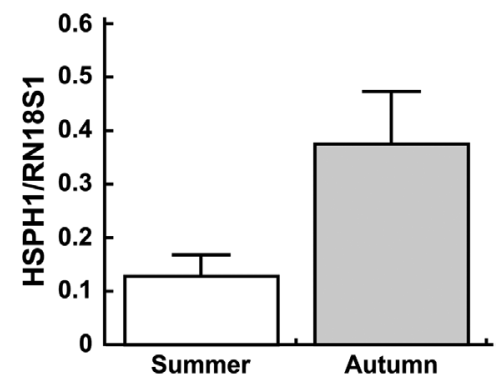

Fig. 1. Changes in relative amounts of (A) glycoprotein 2, (B) neurotensin, (C) E-cadherin and (D) heat shock protein 1 mRNA expressions in the endometrium obtained from the cows in summer and autumn. Data are the means $\pm \mathrm{SEM}$ for six cows per season and are expressed as relative ratios of the mRNAs to 18 S ribosomal RNA (RN18S1). Asterisks show significant differences between summer and autumn $(* \mathrm{P}<0.05)$.

changes may cause, at least, reduced follicular activity, altered ovulatory mechanisms and decreased oocyte and embryo quality. In addition, heat stress increases $\mathrm{PGF}_{2 \alpha}$ production in the endometrium, which might result in early regression of the corpus luteum or death of the embryos $[31,32]$. For example, elevation of the tissue incubation temperature from 39 to $43 \mathrm{C}$ induced a large reduction in conceptus protein synthesis and stimulated release of $\mathrm{PGF}_{2 \alpha}$ by the endometrium. These in vitro results suggest that exposure of pregnant cows to high environmental temperature and humidity may disrupt the balance between the conceptus and endometrial biochemical factors responsible for maintenance of pregnancy [31]. Thus, one might speculate that heat stress during summer affects endometrial conditions as well as follicular development in nonpregnant and pregnant cows as demonstrated in the present study.

The microarray analysis demonstrated that the gene expressions of GP2, NTS, CDH1 and HSPHI in the endometrial tissues on summer were significantly different from their expressions in autumn (Table 3). GP2, which is known as zymogen granule membrane protein, is the major membrane protein expressed in the pancreatic zymogen granules. GP2 is cleaved from the membrane and secreted into the pancreatic duct along with the other digestive enzymes [33]. In the present study, both GP2 mRNA and protein were expressed in the bovine endometrial epithelial cells. The relevance of GP2 to reproduction in mammals is not yet known, and thus the physiological meanings of GP2 in reproductive function remain to be studied. NTS is a 13 amino acid neuropeptide that is closely associated with numerous biological activities in the central nervous system and periphery
[34]. Beside the opioid-independent analgesic system involved in the pathophysiology of various mental disorders, NTS affects food intake, glucose homeostasis, body temperature, behavior and cortisol secretion $[34,35]$. NTS is also known as an anti-apoptotic factor in a variety of cells [36]. In rats, intraventricular injection of NTS resulted in decreasing plasma LH and PRL concentrations [37], and thus NTS is thought to have critical effects on the LH/PRL surge in regulation of the ovulation process. Hence, the higher levels of NTS expressions in the endometrial epithelial and glandular epithelial cells and high concentrations of NTS in plasma during the hot season in this study may account for the suppressed follicular development and subsequently compromised ovulation in the cows.

Heat shock proteins (HSPs) were first identified in Drosophila salivary glands after exposure to elevated temperature [38]. HSPs are classified into different families according to their molecular weights, e.g., 27, 60, 70, 90 and 105/110 kDa [39, 40]. The HSPs have been studied for their roles in protecting cells from elevated temperatures in the process of acclimation to stress or immune responses [41]. Although HSP60 and 70 are known as important factors that protect cells from heat stress in a variety of reproductive organs including the oocyte and placenta [42], there is very little information on HSPH1 $(105 / 110 \mathrm{kDa})$ in the reproductive system. This study is the first to demonstrate that both the gene and protein of HSPH1 were expressed in the bovine endometrium. On the other hand, $\mathrm{CDH} 1$ is expressed within the cytoplasm of trophoblast binuclear cells in the bovine placentome [43]. $C D H 1$ mRNA in day 22 conceptuses was less abundant than in day 17 and day 20 conceptuses [44]. Although 


\section{a) Glycoprotein 2}

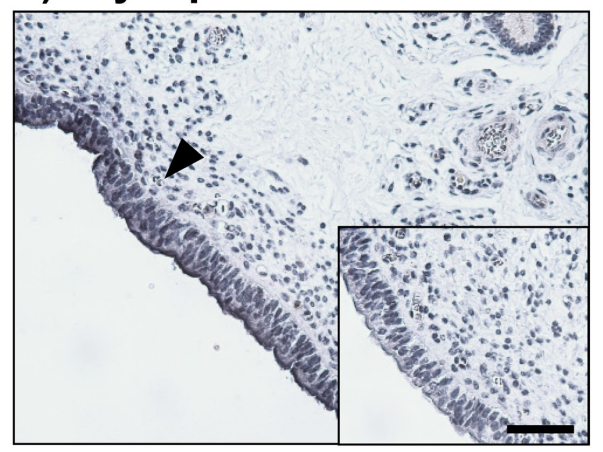

\section{c) E-cadherin}

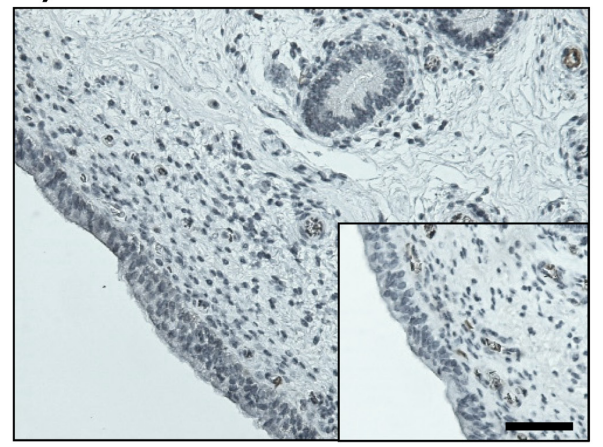

\section{b) Neurotensin}

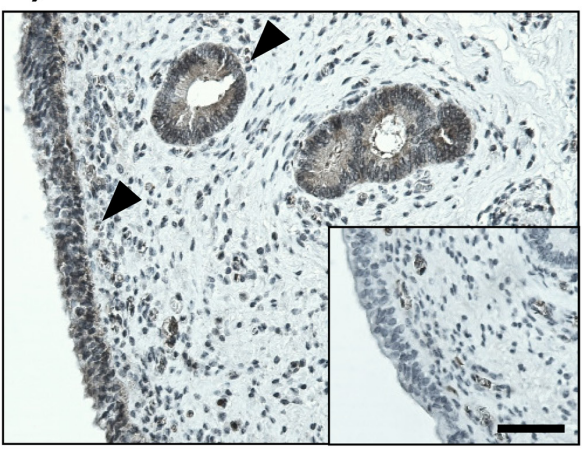

d) Heat shock protein 1

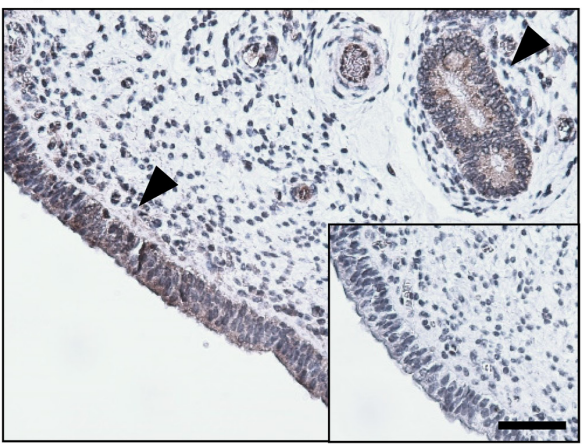

Fig. 2. Localization of a) glycoprotein 2, b) neurotensin, c) E-cadherin and d) heat shock protein 1 in the bovine endometrium evaluated by immunohistochemistry. Intensive immunoreactivities were observed in epithelial or glandular epithelial cells (black arrowheads). No positive immunoreactivity was observed in the negative control (inserted panels). Scale bar $=50 \mu \mathrm{m}$.

(A) Neurotensin

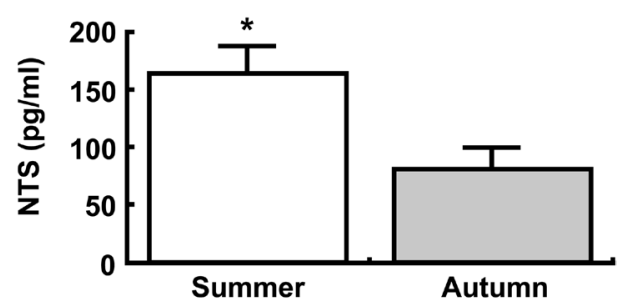

(B) E-cadherin

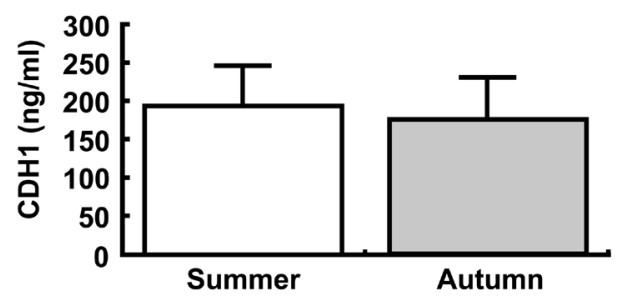

Fig. 3. Concentrations of (A) neurotensin and (B) E-cadherin in the plasma obtained from the cows in summer and autumn evaluated by ELISA. Data are the means \pm SEM for six cows per season. Asterisks show significant differences between summer and autumn $(* \mathrm{P}<0.05)$.
CDH1 mRNA was expressed in the bovine endometrium in this study, positive staining of CDH1 could not be observed by using our immunohistological analysis. Further studies are needed to determine how HSPH1 and CDH1 affect the functional and morphological properties of the endometrium during summer in cows.

Collectively, the changes in gene and protein expressions that we observed may contribute to functional differences in the bovine endometrium between summer and autumn. The substances with altered expression levels in summer may play a pivotal role(s) in regulating uterine function or fetus survival in cows. In addition, since plasma NTS concentrations were higher in the cows under warm conditions rather than cool conditions in this study, NTS as well as GP2 may become useful tools for diagnosis of infertility during summer in cows.

\section{Acknowledgments}

This research was supported by a research program on development of technologies for mitigation and adaptation to climate change in agriculture, forestry and fisheries (44110) from the Ministry of Agriculture, Forestry and Fisheries of Japan. The authors thank the staff of the NARO Tohoku Agricultural Research Center for their skilled technical assistance. 


\section{References}

1. Opsomer G, Gröhn YT, Hertl J, Coryn M, Deluyker H, de Kruif A. Risk factors for post partum ovarian dysfunction in high producing dairy cows in Belgium: a field study. Theriogenology 2000; 53: 841-857. [Medline] [CrossRef]

2. Ryan DP, Prichard JF, Kopel E, Godke RA. Comparing early embryo mortality in dairy cows during hot and cool seasons of the year. Theriogenology 1993; 39: 719-737. [Medline] [CrossRef]

3. De Rensis F, Marconi P, Capelli T, Gatti F, Facciolongo F, Franzini S, Scaramuzzi RJ. Fertility in postpartum dairy cows in winter or summer following estrus synchronization and fixed time AI after the induction of an LH surge with GnRH or hCG. Theriogenology 2002; 58: 1675-1687. [Medline] [CrossRef]

4. Alnimer M, De Rosa G, Grasso F, Napolitano F, Bordi A. Effect of climate on the response to three oestrous synchronisation techniques in lactating dairy cows. Anim Reprod Sci 2002; 71: 157-168. [Medline] [CrossRef]

5. Ray DE, Halbach TJ, Armstrong DV. Season and lactation number effects on milk production and reproduction of dairy cattle in Arizona. J Dairy Sci 1992; 75: 2976-2983. [Medline] [CrossRef]

6. Thompson JA, Magee DD, Tomaszewski MA, Wilks DL, Fourdraine RH. Management of summer infertility in Texas Holstein dairy cattle. Theriogenology 1996; 46: 547-558. [Medline] [CrossRef]

7. Ronchi B, Stradaioli G, Verini Supplizi A, Bernabucci U, Lacetera N, Accorsi PA, Nardone A, Seren E. Influence of heat stress and feed restriction on plasma progesterone, estradiol-17ß, LH, FSH, prolactin and cortisol in Holstein heifers. Livest Prod Sci 2001; 68: 231-241. [CrossRef]

8. Cavestany D, el-Wishy AB, Foote RH. Effect of season and high environmental temperature on fertility of Holstein cattle. J Dairy Sci 1985; 68: 1471-1478. [Medline] [CrossRef]

9. Bernabucci U, Lacetera N, Baumgard LH, Rhoads RP, Ronchi B, Nardone A. Metabolic and hormonal acclimation to heat stress in domesticated ruminants. Animal 2010; 4: 1167-1183. [Medline] [CrossRef]

10. Biggers BG, Geisert RD, Wetteman RP, Buchanan DS. Effect of heat stress on early embryonic development in the beef cow. J Anim Sci 1987; 64: 1512-1518. [Medline]

11. De Rensis F, Scaramuzzi RJ. Heat stress and seasonal effects on reproduction in the dairy cow-a review. Theriogenology 2003; 60: 1139-1151. [Medline] [CrossRef]

12. Amundson JL, Mader TL, Rasby RJ, Hu QS. Environmental effects on pregnancy rate in beef cattle. J Anim Sci 2006; 84: 3415-3420. [Medline] [CrossRef]

13. Roy KS, Prakash BS. Seasonal variation and circadian rhythmicity of the prolactin profile during the summer months in repeat-breeding Murrah buffalo heifers. Reprod Fertil Dev 2007; 19: 569-575. [Medline] [CrossRef]

14. Wolfenson $\mathbf{D}$, Roth $\mathbf{Z}$, Meidan R. Impaired reproduction in heat-stressed cattle: basic and applied aspects. Anim Reprod Sci 2000; 60-61: 535-547. [Medline] [CrossRef]

15. Bényei B, Gáspárdy A, Barros CWC. Changes in embryo production results and ovarian recrudescence during the acclimatisation to the semiarid tropics of embryo donor Holstein-Friesian cows raised in a temperate climate. Anim Reprod Sci 2001; 68: 57-68. [Medline] [CrossRef]

16. Hansen PJ. Exploitation of genetic and physiological determinants of embryonic resistance to elevated temperature to improve embryonic survival in dairy cattle during heat stress. Theriogenology 2007; 68(Suppl 1): S242-S249. [Medline] [CrossRef]

17. Robinson RS, Mann GE, Lamming GE, Wathes DC. Expression of oxytocin, oestrogen and progesterone receptors in uterine biopsy samples throughout the oestrous cycle and early pregnancy in cows. Reproduction 2001; 122: 965-979. [Medline] [CrossRef]

18. Chapwanya A, Meade KG, Narciandi F, Stanley P, Mee JF, Doherty ML, Callanan JJ, O'Farrelly C. Endometrial biopsy: a valuable clinical and research tool in bovine reproduction. Theriogenology 2010; 73: 988-994. [Medline] [CrossRef]

19. Kizaki K, Shichijo-Kizaki A, Furusawa T, Takahashi T, Hosoe M, Hashizume K. Differential neutrophil gene expression in early bovine pregnancy. Reprod Biol Endocrinol 2013; 11: 6. [Medline] [CrossRef]

20. Sakumoto R, Komatsu T, Kasuya E, Saito T, Okuda K. Expression of mRNAs for interleukin-4, interleukin-6 and their receptors in porcine corpus luteum during the estrous cycle. Domest Anim Endocrinol 2006; 31: 246-257. [Medline] [CrossRef]

21. Ushizawa K, Takahashi T, Hosoe M, Kizaki K, Hashizume K. Characterization and expression analysis of SOLD1, a novel member of the retrotransposon-derived Ly-6 superfamily, in bovine placental villi. PLOS ONE 2009; 4: e5814. [Medline] [CrossRef]
22. Roth Z, Meidan R, Shaham-Albalancy A, Braw-Tal R, Wolfenson D. Delayed effect of heat stress on steroid production in medium-sized and preovulatory bovine follicles. Reproduction 2001; 121: 745-751. [Medline] [CrossRef]

23. Roth Z, Arav A, Bor A, Zeron Y, Braw-Tal R, Wolfenson D. Improvement of quality of oocytes collected in the autumn by enhanced removal of impaired follicles from previously heat-stressed cows. Reproduction 2001; 122: 737-744. [Medline] [CrossRef]

24. Wise ME, Armstrong DV, Huber JT, Hunter R, Wiersma F. Hormonal alterations in the lactating dairy cow in response to thermal stress. J Dairy Sci 1988; 71: 2480-2485. [Medline] [CrossRef]

25. Gilad E, Meidan R, Berman A, Graber Y, Wolfenson D. Effect of heat stress on tonic and $\mathrm{GnRH}$-induced gonadotrophin secretion in relation to concentration of oestradiol in plasma of cyclic cows. J Reprod Fertil 1993; 99: 315-321. [Medline] [CrossRef]

26. Badinga L, Thatcher WW, Diaz T, Drost M, Wolfenson D. Effect of environmental heat stress on follicular development and steroidogenesis in lactating Holstein cows. Theriogenology 1993; 39: 797-810. [Medline] [CrossRef]

27. Roth Z, Meidan R, Braw-Tal R, Wolfenson D. Immediate and delayed effects of heat stress on follicular development and its association with plasma FSH and inhibin concentration in cows. J Reprod Fertil 2000; 120: 83-90. [Medline] [CrossRef]

28. Trout JP, McDowell LR, Hansen PJ. Characteristics of the estrous cycle and antioxidan status of lactating Holstein cows exposed to heat stress. J Dairy Sci 1998; 81: 1244-1250. [Medline] [CrossRef]

29. Wilson SJ, Kirby CJ, Koenigsfeld AT, Keisler DH, Lucy MC. Effects of controlled heat stress on ovarian function of dairy cattle. 2. Heifers. J Dairy Sci 1998; 81: 2132-2138. [Medline] [CrossRef]

30. Guzeloglu A, Ambrose JD, Kassa T, Diaz T, Thatcher MJ, Thatcher WW. Long-term follicular dynamics and biochemical characteristics of dominant follicles in dairy cows subjected to acute heat stress. Anim Reprod Sci 2001; 66: 15-34. [Medline] [CrossRef]

31. Putney DJ, Malayer JR, Gross TS, Thatcher WW, Hansen PJ, Drost M. Heat stress-induced alterations in the synthesis and secretion of proteins and prostaglandins by cultured bovine conceptuses and uterine endometrium. Biol Reprod 1988; 39: 717-728. [Medline] [CrossRef]

32. Malayer JR, Hansen PJ, Gross TS, Thatcher WW. Regulation of heat shock-induced alterations in the release of prostaglandins by the uterine endometrium of cows. Theriogenology 1990; 34: 219-230. [Medline] [CrossRef]

33. Yu S, Lowe AW. The pancreatic zymogen granule membrane protein, GP2, binds Escherichia coli Type 1 fimbriae. BMC Gastroenterol 2009; 9: 58. [Medline] [CrossRef]

34. Tyler-McMahon BM, Boules M, Richelson E. Neurotensin: peptide for the next millennium. Regul Pept 2000; 93: 125-136. [Medline] [CrossRef]

35. Mazella J, Béraud-Dufour S, Devader C, Massa F, Coppola T. Neurotensin and its receptors in the control of glucose homeostasis. Front Endocrinol (Lausanne) 2012; 3: 143. [Medline]

36. Devader C, Béraud-Dufour S, Coppola T, Mazella J. The anti-apoptotic role of neurotensin. Cells 2013; 2: 124-135. [Medline] [CrossRef]

37. McCann SM, Vijayan E, Koenig J, Krulich L. The effects of neurotensin on anterior pituitary hormone secretion. Ann N Y Acad Sci 1982; 400: 160-171. [Medline] [CrossRef]

38. Ritossa F. A new puffing pattern induced by temperature shock and DNP in drosophila. Experientia 1962; 18: 571-573. [CrossRef]

39. Lindquist S, Craig EA. The heat-shock proteins. Annu Rev Genet 1988; 22: 631-677. [Medline] [CrossRef]

40. Hatayama T, Takigawa T, Takeuchi S, Shiota K. Characteristic expression of high molecular mass heat shock protein HSP105 during mouse embryo development. Cell Struct Funct 1997; 22: 517-525. [Medline] [CrossRef]

41. Binder RJ. Functions of heat shock proteins in pathways of the innate and adaptive immune system. J Immunol 2014; 193: 5765-5771. [Medline] [CrossRef]

42. Neuer A, Spandorfer SD, Giraldo P, Dieterle S, Rosenwaks Z, Witkin SS. The role of heat shock proteins in reproduction. Hum Reprod Update 2000; 6: 149-159. [Medline] [CrossRef]

43. Nakano H, Shimada A, Imai K, Takahashi T, Hashizume K. The cytoplasmic expression of E-cadherin and beta-catenin in bovine trophoblasts during binucleate cell differentiation. Placenta 2005; 26: 393-401. [Medline] [CrossRef]

44. Yamakoshi S, Bai R, Chaen T, Ideta A, Aoyagi Y, Sakurai T, Konno T, Imakawa K. Expression of mesenchymal-related genes by the bovine trophectoderm following conceptus attachment to the endometrial epithelium. Reproduction 2012; 143: 377-387. [Medline] [CrossRef] 